\title{
The great museum of races
}

With the decline of interest in thuggee and dacoity, and in the years preceding 1857, travel and evangelical narratives displayed little of portent or originality. Most of the organizing tropes - progress, geography, race, gender, religion - had already been established, and accounts were content to rework familiar imagery in harsher detail. Joseph Peggs, who had served as a missionary in Orissa, produced a compilation of lengthy extracts from previous evangelical accounts exposing the horrors of Hinduism in an effort to promote the 'temporal and spiritual welfare of India'. ${ }^{1}$ Howard Malcolm from Boston, USA, recounted examples of Hindu idolatry, and complained of the 'cringing servility' and 'indolent habits' of domestic servants, minutely divided in the tasks they are expected to undertake. ${ }^{2}$ And in the conviction that 'there was no book on India which associated the progress of missions with the history, the literature, the customs, and the mythology of its people, and which combined a general view of this interesting field, with the advancement of the truth', William Campbell penned his thoughts on the prospects for Christianity. ${ }^{3}$ Here his geographical imagination enjoyed free rein in describing the degeneracy of Indian people:

$[T]$ he whole race is destitute of that spirit and firmness, and that courageous daring which distinguish their European conquerors.... [W]hether it be the influence of climate, or the effect of their own depravity, or the fruit of their superstition, or the effeminacy which a long career of despotism is sure to produce, the present Hindoos are the children of a degenerate age, and the veriest dwarfs, when compared with the heroes and the giants of which their history can boast, and who seemed to be more in keeping with the grandeur and magnificence of their country. ${ }^{4}$

In a similar vein, Thomas Jervis, the ardent evangelical and self-publicist, recently appointed provisionally to succeed George Everest as the Surveyor-General of India, ${ }^{5}$ attempted to justify his proposals for a great 


\section{THE OTHER EMPIRE}

trigonometric survey by drawing links between the progress of science and humanity. The endeavour of missionaries to 'civilize and bring over the helpless besotted heathen', he declared in an address to the Geographical Section of the British Association for the Advancement of Science, had been fatally weakened by ignorance of the 'climate, the people, or countries they go to':

We hear of famines, of insurrections, of superstitious and barbarous rites: and are surprised that they should find any place under the milder form of the British sway. To obviate, or alleviate, these evils there is one plain course before us, to know more of the country, and of its people; improving that knowledge to their benefit, and to our honour. ${ }^{6}$

In this endeavour science, in particular geography, had a privileged role to play:

Subserving the important purpose of exploring the darkest recesses of nature, [science] should also light up the darkest retreats of Humanity.... [I]f we really desire success to the one or to the other, to Science or to Missionary enterprise - we must first improve Geography. ${ }^{7}$

This sense of unease about knowledge of India continued also to pervade travel literature. Major Bevan was 'well aware that many valuable works on India have recently appeared', but claimed that in a country so extensive 'much remains to be collected', particularly by someone who has remained there for long periods. ${ }^{8}$ Thirty years in India, Bevan suggests, is sufficient to 'get rid of European prejudices, and to lose those feelings of repulsiveness with which even the most judicious will for a time regard manners and customs essentially different from those to which they have been habituated', and he is critical of the contempt shown by young officers for sepoys under their command, but this does not prevent him lapsing into racist imagery:

Custom, long and deeply-rooted prejudice, and ignorance (connected no doubt, in part, with the physical character of the people, but attributable still more to the nature and effects ... of the religion they profess, or the civil institutions arising from it) have obscured the reasoning powers of the nation, and blunted the measure of ingenuity which they undoubtedly possess, so as to debar them from the attainment of just principles in philosophy, from the discovery of truth in the sciences; and as a consequence ... from a knowledge of the simplest and most effectual processes in the mechanical and other arts. ${ }^{9}$

He adds, with some prescience, that notwithstanding the timidity of Hindu character, 'there are no people whose resentment is more to be dreaded when once they have formed a revolution to obtain revenge ${ }^{\prime}{ }^{10}$ 
James Massie was also sensitive to the inadequate state of knowledge. Despite the multiplication in recent times of travel accounts, he declared, the 'people of England do not know so much of the country, of the people, or the resources of Hindostan, as is desirable for their mutual interest', and he embarked on a narrative that combined personal observation with gleanings from previous accounts. ${ }^{11}$ While dismissing various attempts to retrace the progress of human civilization back to its origins, he acknowledged the 'lamentable truth that myriads of the descendants of Adam ... have reached a depth of degeneracy more frightful and fatal than the gloomiest speculations of these authors'.$^{12}$ He had in mind savages to be found in New Zealand, the Caribbean and the Southern Pacific, but then detected among the tribes of India the same characteristics of cruelty, sensuality, bigotry, depravity and filth. ${ }^{13}$

\section{Urban mythology}

The concern with degeneration and filth signalled in these writings was something of a departure in representations of Indian culture. Earlier manifestations were to be found in accounts of tribals, but striking was the tendency increasingly to locate these pathologies in areas of indigenous settlement at the heart of colonial power. Here the so-called Black Town areas of Calcutta and Madras featured prominently. Descriptions of these areas were part of a nascent urban mythology that requires brief attention. References to Black Town date to the early nineteenth century, and described its isolation from European settlement: an anonymous civilian talked of how 'Black Calcutta (by which I mean that part where the Natives reside) does not at all interfere with the European part, a great comfort, for the Natives are very dirty and their habitations are mere straw huts' $^{14}$ It was in the first topographical surveys, however, that more detailed pictures were to be found. Hamilton's 1820 survey, for example, decribes it:

The black town extends along the river to the north, and exhibits a remarkable contrast to the part inhabited by Europeans. Persons who have only seen the latter have little conception of the remainder of the city, but those, who have been led there by their public or private avocations, will bear testimony to the wretched condition of at least six in eight parts of this externally magnificent city. The streets here are narrow, dirty, and impaired; the houses to two storeys are of brick with flat terraced roofs; but the great majority are mud cottages, ... the whole within and without swarming with population. ${ }^{15}$

For Mrs Holland, the Black Town area of Calcutta provided a home 'for all the people of the earth' as well as 'every tribe of Hindoostanee origin', ${ }^{16}$ while Josiah Conder focused on its plural sensory experience: 


\section{THE OTHER EMPIRE}

A constant creaking of cart wheels, which are never greased in India, a constant clamour of voices, and an almost constant thumping and jingling of drums, cymbals, \&c...; and add to all this, a villainous smell of garlic, rancid coconut oil, and sour butter, and stagnant ditches, and you will understand the sounds, sights, and smells of what is called the 'Black Town' of Calcutta. ${ }^{17}$

In the course of the troubled 1830s, and paralleling the emergence of harsher racial typologies in the metropolis, a distinct sense of urban pathology was constructed around the presence of the poor. Emma Roberts displayed an acute sense of socio-economic differentiation in Calcutta's cosmopolitan population:

The Black Town ... extends along the river to the north, and a more wretchedlooking place can scarcely be imagined: dirty, crowded, ill-built, and abounding with beggars and bad smells. There is, however, a sort of debateable ground between the mud huts, the small dingy brick tenements, and the mean dilapidated bazaars of the middling and lower classes of natives, which is occupied by handsome houses enclosed in court yards, belonging to Armenian merchants, Parsees, and Bengalee gentlemen of wealth and respectability. ${ }^{18}$

For evangelicals like William Campbell, Madras provided Dantean scenes of urban life:

But to behold the whole city given up to idolatry, what a sight! Every object brings their gross and degrading superstition to your view; the mark of the beast is engraven on their foreheads.... Your heart sickens within you, while you pass through the streets of Black Town, and behold crowds of immortal beings busy upon the trifles of the hour, almost ready to devour one another to obtain the riches and vanities of earth, panting after worldly fame and renown ... but all without God and without hope, famishing for want of the bread that endureth to life everlasting, and perishing in their sins. ${ }^{19}$

It was about this time that Major Ormstowe, a resident of many years, conducted James Massie through its streets. The major had difficulty in making sense of the sights they encountered:

What do you call this low, crowded, and almost impenetrable mass of ruinous huts and rude sheds ... with so many entirely naked, squalid, and dirty children running and scrambling about, that it is almost impossible to pass without going over them, through the close, dirty, narrow, and uneven streets? The odour is very offensive, and threatens almost to constrain the mere passenger to inhale infection or disease, from the mixture of decaying vegetation with the secretion of animal matter. ${ }^{20}$

The condemnation of particular constituencies - tribals, criminal bands, the urban poor - has to be seen in the context of more general observations on the Indian people as a whole. Zealous evangelical 
accounts aside, throughout the 1830s and 1840s there was little evidence of a consensus on the state of Indian civilization. Lt. Col. Davidson castigated the 'metaphysicians of Europe' as 'prating jackasses' who 'know nothing of the real nature of man as a sentient being'. ${ }^{21}$ We are arrogant, he proceeded to argue, in overvaluing the results of civilization. Indians may have been without the benefits of Christianity and education, but they are a 'clever people, and generally behave with as much sincere respect to such of us as deserve their good will'. ${ }^{22}$ George Johnson, an advocate of the Supreme Court at Calcutta, considered that harsh judgements of the 'native character' derived from an exclusive concern with the machinations of the litigious, and the cheating of petty merchants. It was as if Englishmen were to be judged on the examples set by 'the well known men of straw about the London law courts, and the petty chapmen and dealers of its Rag Fair'. ${ }^{23}$ Even the Thugs' arch-enemy Sleeman found among the Indian agricultural classes 'some of the best men I have ever known', ${ }^{24}$ and cited with approval the sentiments of Thomas Munro that in general the 'Hindoos are not inferior in civilization to the people of Europe'. ${ }^{25}$

If there was a single work of the time that manifested these tensions, it was the Rev. Buyers's Recollections of Northern India. Prompted by the desire to familiarize readers with the moral knowledge of Indian heathens, the missionary at Benares identified a now familiar litany of pathologies. Black Town Madras contains a far greater number of 'beggars and diseased persons' than any other city he had seen. ${ }^{26}$ Many of these live in a 'very degraded state'. They have an 'unconquerable indolence' which leads them to prefer begging and thieving to honest labour, as a consequence of which it has proved difficult to 'raise them in the scale of society'. ${ }^{27}$ They are cruel to animals, displaying no more care than 'Smithfield drovers, or Whitechapel butchers'. ${ }^{28}$ Sepoys are made up of 'the very dregs of society', and even the more permanent native inhabitants of military cantonments are 'often of a low and profligate character' ${ }^{29}$ Representations of Hindus, on the other hand, rely heavily on eighteenth-century orientalist perspectives. They are 'neither a rude, ignorant people, nor a nation sunk in barbarism'. From early ages they have possessed a 'knowledge of letters, ... written systems of religion, and of morals, as well as philosophy and civil law'. ${ }^{30}$ The common people have a love of poetry, which in its ideas is as beautiful and true to nature as any in Europe. ${ }^{31}$

\section{Nascent ethnology}

No doubt as a response to these manifold tensions and uncertainties, Henry Elliot commenced his pioneering work on the ethnology of India. First published in 1844, his Memoirs of the History, of Folk-lore, and 


\section{THE OTHER EMPIRE}

Distribution of the Races of the North Western Provinces of India was intended to complement H.H. Wilson's ambitious glossary of Indian terms, the first parts of which had just been received. Elliott claimed modestly to 'put together a few notices respecting the tribes, customs ... not hitherto recorded.... [W]e are still almost as ignorant of the agricultural classes of these Provinces as we were on the first day of our occupation. ${ }^{132}$ Entries were arranged alphabetically, as in a gazetteer, but what might have worked for geographical locations proved confusing when applied to the great variety of terms related to tribes, castes and customs. After his death the entries were re-arranged by John Beames into sections on castes, customs, revenue terms, and rural life, thereby establishing the basis for a nascent ethnology.

With the consolidation of military authority and suppression of collective criminal activity, a new-found confidence emerged in the 1850s. Even uncertainties on the state of colonial knowledge seemed to dissipate. Capt. Hervey writing in 1850 stated that India was a 'common topic in the ranks of respectable society.... [E]verybody is becoming conversant with the affairs of that portion of the world, of the very locality of which he was formerly so ignorant. ${ }^{\prime 33}$ In India, the army was firmly in control. Enemies have been defeated, and the native soldiers, with a 'moral courage second to none in the world ... are much attached to their service' ${ }^{34}$ In 1852 J. Gray invited readers to survey India with a 'natural eye ... in these days of sober peace ... when all that is now heard ... is an occasional shot resounding through the Khyber Pass'. ${ }^{35}$

As they took stock of what had been achieved, evangelicals cautiously expressed satisfaction. The Rev. Wylie, a North American missionary, assessed the impact of the British presence in India:

Civilization, trade, the spread of knowledge, the destruction of their political ascendancy, and special legal privileges, tend inevitably to lower the Brahmans every where; and a certain inevitable curiosity about Christianity, as the religion of the governing classes, prepares the way for a favourable reception of its teachers. ${ }^{36}$

He prayed that the 'whole of India may speedily fall under the benignant rule of Great Britain, and ... enjoy the blessing and equal justice, and the elevating influence of rulers who know and love "The Truth"'. ${ }^{37}$ Elsewhere evangelicals made much of detailed information on missionary activity contained in the 40th Report of the Calcutta Auxiliary Bible Society. The past twenty-five years had witnessed extraordinary progress. At a cost of $£ 190,000$ there were now operating in India twenty-two missionary societies employing 443 missionaries, 331 native churches, and 1,347 vernacular schools. Twenty-five printing establishments published the Bible in ten languages and a large variety of tracts. ${ }^{38}$ True, it was a cause for some 
concern that the 'native Protestant flock should be so very small', ${ }^{39}$ but no one could deny that 'many inhuman rites' had been suppressed, that where 'crime and cruelty reigned before' British power was now ascendant, that civilization had progressed, that 'Brahminical influence' had declined, and that the zeal for pilgrimages had fallen off. ${ }^{40}$ The Report's author, Joseph Mullens, also recorded satisfaction that missionary endeavour in the south had assailed the 'bonds of caste, reverence for the sacred books, veneration for a long-established priesthood, and a blind attachment to their idolatories' ${ }^{41}$

The most comprehensive and measured assessment of the state of British India on the eve of the uprising was The Administration of the East India Company; a History of Indian Progress. Written by the Company's historian John Kaye in 1853, it included on the title page a brief extract from Leopold von Ranke's Civil Wars and Monarchy in France: 'the highest praise is due to those who, by their victorious arms, have opened up new scenes for the civilisation of mankind, and overcome barbarism in some important portion of the world' ${ }^{42}$ This, together with title itself, set the narrative. Drawing extensively on published accounts and Company records, Kaye sought eagerly to demonstrate the enlightened nature of contemporary colonial rule:

The servants of the Company have been for nearly two centuries regarding the natives of India only as so many dark-faced and dark-souled Gentiles, whom it was their mission to over-reach in business, and to overcome in war. But out of these hucksters and spoliators had now arisen a race of embryo statesmen with dawning perceptions of the duties and responsibilities of governments and the rightful claims of the people. ${ }^{43}$

Past abuses of power have arisen out of the imperfect state of our knowledge, but now the government is making every effort to perfect its administration; such 'progressive improvement is all that we have a right to expect'. ${ }^{44}$ The problems are considerable. India is a country whose area is 'difficult to compute', whose population is 'difficult to number', and whose people 'present as many varieties of character and language as the entire continent of Europe, and the whole of which are utterly dissimilar to our own'. ${ }^{45}$ Despite these, the record on amelioration of the condition of the people, rationalization of justice, civilization of savage tribes, suppression of cruel abominations, and 'general diffusion of enlightenment and truth' reflect no little honour on the 'Company and its servants' ${ }^{46}$ Of particular merit was the elimination of the threats from Thug, dacoit and tribal activities. Thugee is now so well understood, Kaye declares, that there is not an 'intelligent reader ... who does not know what a Thug is'. Even the word itself has entered into the English language. ${ }^{47}$ Furthermore a few English officers 'have purged India of this great pollution'. As a 


\section{THE OTHER EMPIRE}

system thuggee has been completely destroyed. The 'profession is ruined; the Guild is scattered, never again to be associated into a great corporate body'. ${ }^{48}$

Dacoity also was an institution that for a time resisted the imperatives of colonial knowledge. 'Subdued in one form and in one part of the country', Kaye argues, 'it seemed to take a new life and to break out in another place ... beyond the reach of central supervision.' To grasp the nature of dacoity, gangs were compared to the professional mendicants of London. The 'great outcry' against metropolitan beggars, he pointed out, coincided with the panics about robber gangs in India. There were limits, however, to the analysis, for whereas measures against beggars had driven them into the home counties where there was a 'vast increase in rural mendicity', in Bengal 'dakoitee ... began to centralise itself, and Calcutta was surrounded by banditti' made up of 'an indistinct and heterogeneous posse comitatus' rather than 'a great homogeneous guild or brotherhood' ${ }^{49}$ Thuggee provided the authorities with a trope with which to think dacoity. The 'great idea of the hereditary robber-tribes' was conceived, and the 1843 Act, which extended the policing of and thinking behind thuggee to 'hereditary robber castes', was implemented, leading eventually to the defeat and dispersal of many gangs.

The threat from tribals had also been eliminated. They had once been 'beyond measure lawless and intractable'.$^{50}$ Unsuccessful attempts were made to subdue them by military means, but it was not until the 'work of civilisation' commenced that the culture of violence into which they had been bred and nurtured was displaced by 'habits of peace and industry'. ${ }^{51}$ Much of this had been achieved in the past twenty-five years. In 1825, for example, Bheels were at the 'height of lawlessness'. But the 'schoolmaster has taken the young Bheel in hand' and brought him within the 'pale of civilised life' where he is 'contented to abide'.

Simultaneously, Edward Thornton was engaged on a project to revive Hamilton's pioneering work on the gazetteer. His four-volume Gazetteer of the Territories under the Government of the East India Company was published in 1854, followed three years later by a single-volume digest. This project was designed as an 'epitome of all that has yet been written and published', and yet was rather more, for Thornton successfully fixed the location of considerable numbers of cities, towns and villages, as well as territorial boundaries. ${ }^{52}$

Amidst this groundswell of optimism, however, other more troubled voices could be heard. An 1853 petition signed by 1,800 inhabitants of Bengal pressed for a Royal Commission into the condition of its people. It noted that the system of land tenures and abuse of power by zemindars and planters had demoralized and pauperized the 'labouring classes'. ${ }^{53}$ Relief of this suffering could no longer be delayed, as 'from the information 
they have acquired, they fear that the discontent of the rural population is daily increasing, and that a bitter feeling of hatred towards their rulers is being engendered in their minds'. Full and detailed information was urgently required on the police system, the 'harassing exactions and oppressions to which the poor are subject', the provision of education, and the best means of 'alleviating the sufferings and elevating the condition of the people'. The petition was denied; whether a commission could have prevented the subsequent rebellion is a matter of idle speculation, but when sepoys mutinied against their British officers in May 1857 they set in train a series of events, the grotesque dramaturgy of which was to transform the political and cultural landscape of India, and to influence profoundly British mythology of the subcontinent.

\section{7 and its aftermath}

It is well beyond my remit to discuss the revolt of $1857 .{ }^{54}$ Suffice it to say that its complexities refute generalizations. Seen variously as the first war of independence, a regressive struggle waged by neo-feudal landed magnates, a peasant uprising against oppressive taxation and loss of customary rights over land, and a civil war between collaborators and anticolonial fighters, it was probably all these, and more..$^{55}$ And it cannot be understood as a completely novel and isolated form of struggle. India under colonial rule had witnessed a virtually continuous series of localized revolts or disturbances against the British and their agents. But if the content of 1857 was not unique in Indian history, its scale was; what defined the rebellion was its ability to bring together previously fragmented and uncoordinated struggles, and raise them to new levels of intensity.

The revolt was confined to the northern Gangetic plain and central India. The south, Bengal and the Punjab remained unscathed, although it was the support from the Sikhs, carefully cultivated by the British since the end of the Anglo-Sikh wars, and the disinclination of the Bengali intelligentsia to throw in their lot with what they considered a backward zemindar revolt, that proved decisive in the course of the struggle. The three centres of the revolt reveal something of its lack of cohesion. The sepoy mutiny at Meerut was followed by a march to Delhi where they became a focus for the grievances of landed magnates, artisans and peasants. In Awadh to the east, an autonomous revolt, fuelled by popular resentment against the recent annexation, inflicted a massive defeat on British forces. And in the insecure Maratha districts of Gwalior and Jhansi, rulers and peasants, galvanized by unquenched hostilities, rose up to defeat the British garrison.

We await a detailed study on precisely how mythology of the rebellion was created, but it is clear that the British newspaper and periodical press 
played a crucial role. ${ }^{56}$ By chance, telegraph cables had just been laid. When they worked, information that had previously taken at least thirty days to reach Britain could now be transmitted instantaneously. Reports of the revolt appeared daily in the British press. These were supplemented by articles in reputable periodicals such as Bentley's Miscellany, Blackwood's, British Quarterly Review, Eclectic Review and Fraser's Magazine. ${ }^{57}$ Such reportage, in particular of the atrocities allegedly committed by the mutineers, no doubt boosted sales, but more importantly they shook to the very foundation any confidence in the information order and in the Company's administration of Indian affairs. In this uncertain climate evangelicals went on the assault, resurrecting the most virulent representations of Indian people. Under the rubric 'The heathen, thine inheritance', John Stevenson sermonized on the 'unexpected and tremendous stroke' that has 'paralyzed all England like an electric shock':

Sons and daughters of England, unoffending missionaries, women and children, have been barbarously tortured and murdered, with a refinement of cruelty that can be paralleled only by the infernal demons. All the tortures we read of in the Romish inquisition and persecutions, or the torments inflicted by American savages upon their captives, had comparatively a touch of mercy. ${ }^{58}$

This relegation of Indians in the chain of being was accompanied by calls for severe retribution to 're-establish that empire of opinion; - that conviction of our supremacy, and of the irresistible superiority of the AngloSaxon race, on which the rule of the British in India depended'. Blame for the outrages was placed firmly at the door of the Company. It has pursued 'worldly gain' at the cost of promotion of Christianity. Only the 'simple operation of wise and good government' can regenerate the 'diabolical depravity of the "natural man"' by attracting him to 'our rule'. ${ }^{59}$

Francis Close, Dean of Carlisle, in a retrospective view of the revolt remembered not only the 'horrors ... on every tongue, and successive telegrams [that] made every heart palpitate', but also the indignation aroused against the 'crooked policy of government, and their cowardly abandonment of religious principle' ${ }^{60}$ The same concern was expressed by the Presbyterian missionary James McKee. The reason why India has lagged so far behind the South Sea Islanders in their progress toward civilization is that 'Hindooism is one of the most formidable systems of error ever Satan reared ... the greatest obstacle to progress - the all but insurmountable difficulty against which we have been contending - is, HINDOOISM SUPPORTED BY THE BRITISH GOVERNMENT' ${ }^{61}$ Meanwhile, the Rev. Murray Mitchell, missionary of the Free Church of Scotland at Bombay, noted the lessons that had been learnt. Until recent events, there was a tendency to 'speak in very mitigated condemnation, not to say approba- 
tion, of heathen religions'. ${ }^{62}$ This 'grievous folly', however, has now ceased, and no one denies that 'the dark places of the earth are full of the habitations of cruelty', and that the heathen are 'without understanding, ... implacable, unmerciful'. The natives of India have a 'character combining many of the attributes of the child with the savage, with a tendency to rush ... from one feeling to the opposite'. Under these circumstances,

that device of which many of us were so fond, that of divide et impera - of playing off the prejudices of one Indian race against another ... has been proved to be utterly fallacious. Moslem and Hindu can unite for a time against the Christian foreigner, although, the moment he is disposed of, they are ready to fly at each other's throats.... Not until India is Christian will her endlessly varied and jarring races coalesce into true union and harmony, [and] either the principles of our rule be understood, or its burden be endured, except with sullen, smouldering discontent and hatred. ${ }^{63}$

Expressing faith in the impulses of modernization, however, Mitchell argues that public improvements are taking place on an unprecedented scale. These will provide propitious conditions, he concludes, for the 'Oriental mind is touched by the spirit of European progress' and Christians will bring Indians willingly to the 'cause of truth' ${ }^{64}$

Travel narratives of the time display the same intensification of racial attitudes. The rich young sisters Madeline and Rosalind Wallace-Dunlop decided to visit their brother in Meerut, returning to England a month before the mutiny broke out. Their journal was published in $1858 .{ }^{65}$ 'One only has to glance at this work', suggests Ketaki Kushari Dyson, 'to understand how inevitable the rebellion of 1857 was', $^{66}$ for beneath the lighthearted descriptions of the frivolities of British life in India there is a thinly disguised contempt for Indians, especially rural labourers. Their culture, colour, language, smell and appearance are all described, but in ways that seem to convey a sense of the unreality of an apocalyptic other-worldliness. Porters who carried the sisters' carriage across a river were seen as a 'swarm of yelling, screaming black Coolies'; mid-stream the sisters were 'surrounded by water, and completely at the mercy of a set of demon-like beings' ${ }^{67}$ At a village fête, one of the sisters remarked, 'the hideous music, yelling, and shouting, nasal singing, uncouth gestures, and strange garb of these demoniacal looking natives, strongly reminded me of the pictures of Pandemonium' ${ }^{68}$ At a distance Rajput women appeared 'very becoming', but a 'nearer approach dispels the illusion. Their clothes are filthy dirty, and their hair guiltless of any attempt to smooth or arrange it. ${ }^{169} \mathrm{Commu}-$ nication was a problem. Before leaving England the sisters were given a copy of 'Forbes Manual' to study. They found it 'utterly useless' for the phrases were 'far above the comprehension of common servants'. In contrast, 'Hindostanee ... is a frightful language, only sounding pretty from 
the rosy lips of little English children, a medium that might beautify any jargon' ${ }^{70}$ None of this, however, can be explained as reactions of guileless young travellers. If anything, their brother Robert, Magistrate at Meerut, expressed an even stronger sense of racial and class contempt for Indians. He had the 'most absurd horror of a native's coming near him: he declared he could detect the copperish smell of the colouring matter in their skins the instant they entered the room, and he would much sooner be touched by a toad than by one of their clammy hands'.$^{71}$

Nor were seasoned journalists exempt from the use of such rhetoric. The special correspondent of The Times, William Russell, who had been sent in 1858 to cover the suppression of the rebellion, described the approach to Calcutta:

It was a most wonderful and striking picture - nothing I have ever seen came near to it for variety and effect. The black figures, streaked with white waistbands and turbans - the contrast between the repose of the groups seated near each fire with the energetic, active, and ceaseless movement of those who were running about - ... those wild weird men dancing like demons. 'Pooh! what is this dreadful smell - like - like coarse roasting meat?' I glanced at my companion ... and in reply to my look, he said, 'It's one of the BURNING GHAUTS! Boatmen! boatmen! pull for your lives!'.... I remember such another horror in an old book of travels - 'cannibals feasting by moonlight. ${ }^{172}$

The eponymous Cadwalladar Cummerbund called on artistic and literary imaginations to describe the seemingly ineffable bazaars of Calcutta:

But though insuggestive of the poetical, Calcutta bazaars afford a fine field for the talents of such men as Leech and Dickens; the former might find grotesque subjects for his pencil at every step, and the latter could alone do justice to their ridiculous characteristics. For want of a master mind to evolve it, what a mine of drollery remains yet undeveloped in the antediluvian appearance of the gharries patronized by the poorer classes of babboos.... $[T]$ hese and a hundred other odd sights peculiar to Calcutta, yet await a 'coming man' to place them vividly before the mind's eye. ${ }^{73}$

He also surveyed the 'dusky Venuses' at that privileged site of imperial concern, the Churrock Pooja, and expressed disappointment. Thick lips and bluff noses are not poetical images, he declared. 'What', asks some sceptical young lady, 'were their eyes not black, then?':

Most assuredly, my dear, but so were their skins.... Your beautiful blue or jet black orbs ... contrast with cheeks blending the lily and the rose, and a swanlike neck of pearly whiteness ... but, black cheeks - black lips - black neck black hair - black everything! what do they picture but a chimney sweep? $?^{74}$

The events of 1857 impacted on British colonial policy. Conventionally thought as constituting a profound rupture, they are better seen as a 
quickening of measures that had already been set in motion. Following years of growing disaffection with the Company's management of Indian affairs, control was finally wrested by the government, and placed in the hands of a Secretary of State for India. Queen Victoria made conciliatory gestures in her proclamation of 1858 . She promised benevolent rule, and an end to the corrupt failure to abide by the terms of treaties entered into with Indian princes. The army switched recruitment to the Punjab and Nepal, plunging the previously favoured areas of Benares and Awadh into economic recession. Simultaneously, the proportion of European troops was doubled. In order to restore finances after the massive debts incurred by 1857 , an income tax was levied on urban elites; more fundamentally, the political economy of India was oriented toward the export of agricultural raw materials.

In this period of post-traumatic shock and ensuing stabilization more measured responses to Indian affairs were heard. Kaye, who had written with such calm authority on the good government of the Company, now reflected cautiously on its collapse. His History of the Indian Mutiny, commenced in 1864 but published over thirty years later, points to a profound failure of the information order. ${ }^{75}$ The empirical knowledge accumulated on India was unable to predict the revolt because it had revealed nothing about Indian customs and beliefs except their outward appearances. The events of the revolt cruelly exposed these weaknesses. Local information networks operated effectively to convey news among the peasantry, but in ways that mystified colonial authorities. The infamous case of chapatis passed from village to village, somehow portentous of a momentous event, created an instant myth emblematic of the unease at the core of colonial knowledge. ${ }^{76}$

Robert Montgomery Martin, who had thirty years previously made available the pioneering survey of Francis Buchanan, also considered the state of India. The 'calamitous tempest' of 1857-58 swept away fictions of the 'Company's dominions', and we have been brought to face the truth that 'England has become identified with Hindostan'. ${ }^{77}$ The recent government of India has been found wanting of those necessary virtues of Christian justice, mercy and charity, but there is reason to hope that parliamentary and public opinion are coming to recognize the 'primary duty and even political expediency of Justice to India' ${ }^{78}$ Some of the problems that beset the previous administration remain. The 'wild races' such as Mughs and Kookis which live in a savage state east of Bengal continue to plunder villages, forcing inhabitants to desert them. 'Prejudices of caste, of creed and custom' obstruct the creation of national unity among the 'millions of heterogeneous races', and it may be many years before they ultimately yield to the 'humanizing influences of a higher civilization' and so prepare 'all classes for national freedom and self-government' ${ }^{79}$ And 
yet the new administration is a modernizing one. Past treatment of the people of India as inferior is passing; the new functionaries are from every stratum of British society, and they are brought into contact with 'intelligent and gentlemanly Hindoos'. The spread of education, instruction in medicine, engineering and the 'higher branches of human knowledge', and promotion of 'unfettered enterprise and capital' will 'raise the tone of native society, and enable the upper classes of both races to meet on a more equal footing'. ${ }^{80}$

Sensitive to a more religious modernity, the Rev. John Barton inquired into the impact on the 'Hindu mind' of forty years' contact not only with 'missionary effort, but with the indirectly Christianizing influences of English literature, English political and commercial activity, and, above all, of a government which ... has always been conducted ... with the most scrupulous integrity' ${ }^{81}$ The results, he concluded, were far more momentous than those which the 'railroad progress of scientific discovery has effected within the last century in England'. Few were more involved in this modern civilizing mission than Mary Carpenter. ${ }^{82}$ She proudly included a passage written in her notebook by her host, S. Tagore, an Indian Christian:

What was India a few years ago? ... We see a nation domineered over by caste and idolatry - a nation of which the men are completely enslaved to custom, and the women kept down and tyrannised over by the men ... a nation which has long since ceased to be progressive, and of which inertia and stationariness is the natural condition.... India sank down under the weight of the accumulated corruption of ages; foreign influences were requisite to rouse her. ${ }^{83}$

It could well have been Carpenter's anthem, for as a committed educator and reformer she did much during her time in India to promote the education of the young as a means of overcoming this inertia. In an address on the reformatory school system, Carpenter drew out the lessons from recent intervention of the British. Twenty years ago, she said, a number of benevolent reformers had tried to educate children from the very lowest orders, not to 'raise them out of their proper spheres, but to enable them to work honestly and fitly for their appointed vocations'. The result was a gradual conversion of 'young savages into respectable men and women'. ${ }^{84}$ Such reforms could with benefit be introduced in India, although, she added, the lot of a class even lower than these - the roving street Arabs will continue to exercise the 'best and deepest thinkers, and students of political economy ${ }^{\prime} .{ }^{85}$ So too will the many tribes in the hills who live in a 'completely savage state ... almost entirely unclothed, and looking as if a civilized idea never entered their heads'. For until

we make every effort ... to educate those who are more within our reach ... and we have taught them a language which will bring them into sympathy, 
not only with their rulers, but with the educated portion of their countrymen, we shall have little hope of reaching the barbaric life in our midst. ${ }^{86}$

At the heart of Carpenter's concerns, therefore, lay fears about the existing state of knowledge of India. 'The British public', she wrote, 'is ... very little informed of the actual condition and wants of that great country and its inhabitants, beyond what may be gathered from official or from missionary reports.' Any progress was entirely dependent upon a 'more familiar knowledge' between both countries. ${ }^{87}$ Doubtless to this end she was instrumental in establishing a Bengal branch of the Social Sciences Association of Great Britain, with areas of interest and inquiry in law, education, health, trade, labour and agriculture. ${ }^{88}$

Despite continued anxieties about the information order, with political stabilization came a renewed sense of optimism about the future of colonial rule. During a sermon delivered at Westminster Abbey at the consecration of George Cotton as Bishop of Calcutta in 1858, the Rev. Vaughan declared that 1857 had given missions a political prominence that they had not received since 1813. Some extreme sentiments were expressed on the danger that they posed to the future of the empire, but calmer and more moderate voices had prevailed. These urged the need for wisdom and a deeper sense of responsibility towards India; calls were renewed for 'labourers in that great field of evangelistic work', a special fund was established, missionary studentships were formed, and a new bishop was 'sent forth to quicken the energies and regulate the labours of missionaries ... [and] to build up again from its ruins a Church distressed and desolate and baptized in blood ${ }^{\prime}{ }^{89}$ Cotton himself later recorded in his journal that he 'dwelt with mixed feelings of regret and hopefulness on the well-known fact that it was chiefly among the lowest castes ... that Christianity had made ... substantial progress, ... and looked to the introduction and improvement of the ryots, and to the extension of female education throughout India, as the most hopeful agency for promoting the ultimate evangelisation of the country'..$^{90}$

William Butler, entranced as a child by 'amazing descriptions of Oriental magnificence recorded by Sir Thomas Roe' and other tales of the Mughal court, now recognized that the authors had drawn largely 'upon their imagination'. ${ }^{91}$ Armed with this, he attacked the enemies of Christian civilization. Brahmans 'hate that republican Christianity which declares that "God hath made of one blood all nations of men"'. There was a time when they could be regarded as the 'learned class of India', but education has moved on, rendering their chronology, geography, astronomy and history 'wild and exaggerated falsehoods'. ${ }^{92}$ Above these 'elements of wrath and hatred', however, were the 'criminal classes ... who only needed the sanction of their Brahmins and Fakirs' to rise up in their 'hour of 
opportunity against the Christian civilization', fought against Christian knowledge for 'possession of the bright land of the Veda, and for the perpetual supremacy over its 200,000,000 men!'93 In this struggle for supremacy, Butler was able to report, there had been a dramatic increase in missionary activity since $1857 .{ }^{94}$

In no area was this more evident than in women's missions, which expanded rapidly in the decades after 1857. As in the metropolis, women had previously played an auxiliary role in evangelical endeavour. For the most part women were expected to support the activities of male evangelicals, although occasionally, because allowed exclusive access, they had pioneered house-to-house visitations, particularly to the zenanas, the female areas in high-caste households. Amidst fears that the rebellion had taken place because of corrupt ideas taught by heathen mothers, emphasis was now placed on the moral regeneration of indigenous families..$^{95}$ Thus in a move mutually reinforcing that in the metropolis, new opportunities were provided for female evangelicals to promote English middle-class domestic ideals through extended house visitations.

Similar, but perhaps more guarded optimism was expressed over ten years later by Herbert Blackett, late of the Cambridge Mission to Delhi. Despite the large and increasing numbers of missions now working in India there remains about one missionary to every 500,000 people. Furthermore, Christianity faces many serious obstacles. Apart from the difficulties of the caste system, the moral and intellectual condition of the people is low. Under these circumstances, the wonder is not that so little but that so much has been achieved. There are signs of transition, for even if the effects of Christianity are not yet palpable, the influence of English government and education is felt everywhere. The 'iron rules of caste' have been mitigated by modernizing impulses of education and the railways, and the 'ancient reverence for Brahmans has suffered much'. ${ }^{96}$ James Bradbury, thirty-four years in India as a LMS missionary, looked optimistically to the potential for conversion among aboriginal tribes:

$[\mathrm{N}] \mathrm{o}$ institution was ever formed that afforded greater facilities to strengthen the arm of oppression and uphold the reign of terror than caste.... The absence of a corrupt priesthood in most of the tribes will, in the event of missions being established among them, contribute in no ordinary degree to their moral and spiritual improvement. No set of men ever exercised a more powerful and destructive influence over a people and maintained it under a better appearance of outward sanctity, than the brahmans. ${ }^{97}$

The record of missionary activity among tribes previously thought the most potent threat to colonial rule was particularly pleasing:

The results to evangelize the mountaineers and foresters is of an encouraging nature. The mission among the Coles, who inhabit the hilly country of 
Chota Nagpore, is one of the most prosperous in the Bengal presidency. More than 40,000 of the tribe have embraced the Christian faith. ${ }^{98}$

Travel accounts of the time reproduced more strident racial stereotypes, particularly of tribal peoples. In 1871 E.C.P. Hull's new vade-mecum appeared, which attempted to 'fill the void' in ordinary handbooks by describing everyday life in India. ${ }^{99}$ In India, it informed the readers, there are 'many different races, bearing little resemblance to each other'. In general the Hindus have 'handsome, well-formed features.... Here is the open forehead, the aquiline nose, the well-cut lip.' Some of the 'hill or jungle tribes', however, possess characteristics 'which one is accustomed to look for only in Africa - frizzled hair, thick lips, and flattened nose.... Others are similar as to nose and lips, but have coarse, dark hair, not unlike the aborigines of Australia. ${ }^{100}$ In rather more interesting ways, Hull outlined the promise of Western modernity in the post-1857 era:

Then when we get into the railway carriage, and are whirled way at thirty miles an hour, what an incongruity we ourselves become! Sped along by the iron horse, we pass villages of the fashion of 2000 years ago; huts and temples and cultivation, repeated from generation to generation.... [T]he annihilation of the rebel armies of 1857, produced a conviction among the people of India of the irresistible sovereignty of Anglo-Saxonism over their country, and with such a conviction immense obstacles to the progress of European civilization must necessarily be removed. There now appears ... the promise of a long period of calm having dawned on the political horizon of India. ${ }^{101}$

The most popular and authoritative handbooks, however, were the series prepared by Capt. Eastwick, and published over 1859-83. ${ }^{102}$ The preface to the first edition spoke of 'special want' for a handbook now that England and India have been brought closer by 'almost continuous steam communication, ... the electric telegraph', and by a 'sympathy which even the recent abortive attempt to dissever the two countries ... has tended to evoke'. The vastness and diversity of India, however, and the uncertainty of information we have 'render a Handbook of India a much more arduous undertaking than the Handbook of most other countries'. To address these problems, and provide a work 'as useful as possible to the servants of government, and persons resident in India, as well as the mere traveller', many detailed statistics and much primary information have been provided. ${ }^{103}$ Included were figures on population from the Census, although this did not prevent recourse to racialized classifications. In Bengal, for example,

we have a people physically distinct from any other people in India. Living in a network of rivers and morasses, and nourished on a watery rice diet, the semi-amphibious Bengali in appearance belongs to a weak and puny race.... 


\section{THE OTHER EMPIRE}

[T]he Uriyas have developed a peculiar physiognomy and character from their isolated position. They are even more timid than Bengalis. Conservative to a degree, they are wanting in enterprise, evidence a thorough dislike of all modern improvements, and are the most bigoted priest-ridden people in India... The Hindustanis of Bihar ... are more decidedly Aryan than any of the other races of Bengal, and partly from climate, partly from their more substantial diet, and partly from a larger infusion of Aryan blood, are hardier and more manly than the Bengalis. ${ }^{104}$

This concoction of environmentalism, physiology and genetics is applied to the various peoples encountered to produce a consciously hierarchical taxonomy. The Thakars of the Punjab hills are a 'good looking and well made race', the Paharis of Kashmir a 'strong, hardy race, of a powerful frame, [with] straight foreheads, and noses markedly hooked', the Kolis are 'undoubtedly aborigines, and belong to the dark races', and the Waralis have hair 'black and lank, their bodies were oiled; and altogether they had a very wild appearance'.

The 1857 rebellion had exposed the inadequacies of the information order. Once the shock waves had died down, colonial authorities, evangelicals and reformers, many of whom saw themselves as modernizers, began to address with renewed urgency the attendant demands for relevant and reliable information. They were abetted by a rapid expansion of the communications network, and the establishment of educational institutions, printing presses and libraries by an English-educated elite. ${ }^{105}$ With some irony, though, this same expansion in communications promoted the development of indigenous forms of information, and these came to challenge the dominant order, exerting even more pressure to maintain its authority. Information, however, was not the same as knowledge, and so no amount of empirical detail was guaranteed to provide understanding of India's diversity. Prior to 1857 evangelical narratives, travel accounts and surveys attempted to capture this through a totalizing vision based on empirical observation. Now, under pressure to reform, and out of a recognition of epistemological failure, totalization not only intensified but was organized by certain assumptions about the essential features of Indian society. It was at this moment that traditional India was discovered, and caste emerged as the great metanarrative of Indian culture.

\section{Discovery of caste}

The notion of caste emerged during the formative stages of the British imagination of India. The first serious attempt to understand Hindu mythology in its own terms, Henry Lord's Discovery of the Sect of the Banians (1630), discussed the creation of the caste system, and Ovington's A Voyage to Surat in the Year 1689 found among the banias twenty-four 


\title{
THE GREAT MUSEUM OF RACES
}

'casts, or Sects, who both refrain from an indiscriminate mixture in Marriages, and from eating together in common'. ${ }^{106}$ It was not until the end of the eighteenth century, however, that caste was subjected to scholarly analysis. William Robertson's survey of ancient India included a detailed examination of the caste system:

Such arbitrary arrangements seem ... to be adverse to improvement either in science or in the arts; and by forming around the different orders of men artificial barriers, which it would be impious to pass, tend to circumscribe the operations of the human mind within a narrower sphere than nature has allotted to them.... The regulations of Indian policy, with respect to the different orders of men, must necessarily check genius in its career, and confine to the functions of an inferior cast, talents fitted to shine in an higher sphere. ${ }^{107}$

The objects of civil government, however, are to meet the needs of the many rather than the few. The first Indian legislators, therefore,

\begin{abstract}
set apart certain races of men for each of the various professions and arts necessary in a well ordered society, and appointed the exercise of them to be transmitted from father to son in succession. This system, although extremely repugnant to the ideas which we ... have formed, will be found ... better adapted to attain the end in view, than a careless observer, at first sight, is apt to imagine. ${ }^{108}$
\end{abstract}

Concurrently, the French Jesuit missionary Abbe Dubois completed his Description of the Character, Manners, and Customs of the People of India, which with the active support of British authorities was published in English in 1816. ${ }^{109}$ Dubois confronted criticisms of the caste system as useless, ridiculous and a threat to good order:

I believe caste division to be in many respects the chef-d'oeuvre, the happiest effort, of Hindu legislation. I am persuaded that it is simply and solely due to the distribution of the people into castes that India did not lapse into a state of barbarism, and that she preserved and perfected the arts and sciences of civilization whilst most other nations of the earth remained in a state of barbarism. ${ }^{110}$

Thus, for Dubois, the caste system kept 'within the bounds of duty' the lower orders of Indian society, who without such moral restraint would have lapsed into a state 'worse than the hordes of cannibals'. It had also preserved Indian laws, religions and customs from foreign invasion. Under these circumstances, Dubois reasoned, Christianity was doomed to fail in India, and colonial authorities should refrain from undue interference in Indian culture.

In the period leading up to the adoption of the pious clause in 1813, these views held sway among Company officials and did much to bolster 
opposition to evangelical activity. And they survived for some time after. Anglican missionary societies such as the Society for Promoting Christian Knowledge and the Society for Propagating the Gospel - ever suspicious of evangelical zeal - considered caste a religious ordering with which missionaries should not interfere. Heber's sympathy for Indian culture led him to counsel tolerance for practices that were institutional or cultural rather than purely idolatrous. ${ }^{111}$ These sentiments could even be found among influential circles as late as 1858, when Bishop Cotton opposed a move to abolish the caste system on the grounds that in the absence of the civilizing influence of Christianity it prevented India from collapse into anarchy. ${ }^{112}$ The assault by evangelicals, however, gradually weakened its hold, and over time, particularly when inflected by racial coding, the negative stereotype of a caste-ridden Hinduism intensified.

Caste attracted the hostility of evangelicals because it was seen as a powerful barrier to conversion, enlightenment and progress, and the mainstay of arguments against intervention in Indian customs. And yet caste was understood with neither rigour nor consistency. Dubois's support for caste had coexisted with a revulsion toward Hinduism, as if the former was a civil institution. Others such as William Carey saw the two as mutually supportive and inextricable. Lacking precision, the term caste was used interchangeably with race, sect, tribe and even nation to denote a population seen to possess common traits. Indeed, it was this versatility that promoted the cavalier use of caste to provide pseudo-scientific status to theories on the nature of Indian society. Charles Grant considered caste to be one of the defining features of 'Hindoo character', and as an example described dacoits as 'castes of robbers and thieves'. ${ }^{113}$ For others, caste was a means of explaining differentiation. James Forbes subdivided the four varnas into eighty-four castes, attributing differences to geographical factors, and spelled out the implicit racial hierarchization when he noted that 'inferior castes are of a darker complexion than the superior Hindoos'.114

We might have expected better of James Mill. His damning indictment of Indian history and culture, published in the same year as the study of Dubois, was written with customary utilitarian rigour. And yet the History of British India falters on the matter of caste. Mill's target was Brahmanism, which he considered a despotic system of priestcraft that had for centuries enslaved the Indian people. Ideologically, it was sustained by gross superstition, socially and politically by caste. In caste, he thus proposed, we have the key to understanding India: 'On this division of the people, and the privileges or disadvantages annexed to the several castes, the whole frame of Hindu society so much depends that it is an object of primary importance and merits full elucidation'. ${ }^{115}$ This was not a work, however, of sociological sophistication. On Mill's voyage to discover in caste the essence of India he was not equipped with the tools of social 
analysis, let alone the eyes of a diligent observer; his idea of caste was purely textualist. ${ }^{116}$ For despite hostility to the benign views of orientalists on the achievements of Indian civilization, Mill derived his understanding of caste almost exclusively from their work on ancient vedic scripts, in particular Jones's translation of The Laws of Manu. The result was a routine account of the varnas, which was then used inconsistently to expose the corrupt, absolute and enervating nature of Brahmanic authority. ${ }^{117}$

During the troubled period of colonial expansion when a certain loss of faith occurred in the promise of missionary endeavour, Brahmanic tyranny more than the caste system per se was viewed as the rotten core of Indian society and the barrier to progress. William Ward's influential study A View of the History, Literature, and Religion of the Hindoos sought to understand the universal appeal of idolatry and superstition. The many coincidences in mythologies of heathen nations, he surmised, have arisen from the 'common depravity' of men who reject Christianity. The manifest effect of idolatry 'is an immersion into grossest moral darkness'; 'no where have these features presented a more disgusting and horrible appearance than among the Hindoos', ${ }^{118}$ for the Hindu system is 'wholly the work of brahmuns' who have 'placed themselves above kings in honour, and laid the whole nation at their feet'. ${ }^{119}$

Here was a theme that, drawing upon Protestant myths of an idolatrous, priest-ridden papacy, ${ }^{120}$ or the anti-clericalism of the Enlightenment, could unite the followers of both Dubois and Mill. In contrast, the idea of caste was more contentious and seemingly less amenable to empirical observation, as a result of which it continued to be used loosely as a descriptive term. Walter Hamilton's pioneering survey of 1820, for example, noted that 'were it not for the uncharitable operation of caste, [the Bengalese] would be a friendly and inoffensive race. They have a thorough contempt for all other nations and castes ... whom they consider impure and degraded. ${ }^{\prime 21}$ Lt. Col. Fitzclarence, scourge of the Pindaris, saw Christian converts as 'the vilest wretches of the lowest class, or of no caste', who choose to call themselves of 'master's caste'. ${ }^{122}$ And Francis Buchanan blamed the 'doctrine of caste' for the large presence of the necessitous poor. ${ }^{123}$

Until 1857 the notion of caste was little developed beyond its use to understand criminal and tribal activity. ${ }^{124}$ Despite the continued lack of precision, a certain consensus was established in Protestant circles on its inherent malignancy. Wilson, Bishop of Calcutta, summed up the prevailing mood:

The distinction of castes ... must be abandoned, decidedly, immediately, finally... The Gospel recognizes no distinctions such as those of castes, imposed by a heathen usage, bearing in some respects a supposed religious 


\section{THE OTHER EMPIRE}

obligation, condemning those in the lower ranks to perpetual abasement, placing an immovable barrier against all general advance and improvement in society. ${ }^{125}$

After reverberations from the revolt had died down, colonial authorities, now under the direct control of the British state, turned to the serious and urgent task of providing more systematic, comprehensive and classified knowledge of Indian people. This was not a radical shift in strategy. As we have seen, from the time of Buchanan's surveys early in the century, various attempts had been made to survey aspects of Indian culture and polity. They tended to have a regional basis, or were focused on particular types of information such as settlement or land revenue records. But it was these surveys - partial, diverse and incommensurable - that set the stage for the massive ethnological project of the post- 1857 period.

Certain clearly defined objectives had to be met. To prevent mutinous impulses in the army, 'brahmanized' Indians needed to be replaced by recruits from manly, 'casteless' (and hence safer) areas such as the Punjab and Nepal. And in order to reduce pressure on peasant populations that had joined the revolt, the first moves were made to extend representative power to small groups on provincial legislative councils. ${ }^{126}$ Overall, however, the sense of urgency sprang from the recognition of inadequacies in the knowledge order due not only to the paucity of reliable comparative data, but also to the epistemologies that had so inconsistently and unsuccessfully framed previous knowledge production. Solutions were sought in the discipline of ethnology, the emergence of which in this period was prompted by a desire to confer scientific status on the human sciences through quantitative work on people in the 'laboratory of mankind' ${ }^{127}$ But if the perspective was provided by ethnology, the focal point was caste, thought no longer in doctrinal or academic terms, but as a matter of colonial policy.

The literature created by this project is so vast it demands separate study. ${ }^{128}$ All I can do here is attempt to bring out some of the more significant features. Two projects dominated knowledge production in India during the second half of the nineteenth century. The Census was introduced in the 1850s, and initially was organized on a provincial basis. ${ }^{129}$ Thus the North-Western Provinces were surveyed in 1853, and the Punjab in 1855. Plans for the introduction in 1861 of an all-India decennial Census along the lines of that of Britain were thwarted by the rebellion. The first was therefore undertaken in 1871. Over time it grew into the most extensive enumeration of a population ever taken; the 1961 Census, completed nearly twenty years after its inception, appeared in over 1,600 volumes.

In the shadow of the Census, and dependent upon it for much of the statistical data, was The Imperial Gazetteer. Although a series of studies 
was inaugurated with the ill-fated Buchanan surveys, and followed by Hamilton and Thornton, serious work began in 1869 when William Hunter was directed by the government to undertake a statistical survey of India. Unhappy with the meagre and 'heterogeneous incompleteness' of previous local surveys, most of which had involved extravagant outlays, the Governor-General required Hamilton to visit the various provincial governments with a view to 'submit a comprehensive scheme for utilizing the information already collected; for prescribing the principles' to be adopted; and 'for the consolidation into one work of the whole of the materials that may be available' ${ }^{130}$ The models he chose were Aini-iAkbari of 1580 and Napoleon's Description de L'Egypt of 1821: 'It was my hope', he declared, 'to make a memorial of England's work in India, more lasting, because truer and more complete, than these monuments of Mughal Empire and of French ambition':

Nothing is more costly than ignorance. I believe that, in spite of its many defects, this work will prove a memorable episode in the long battle against ignorance; a breakwater against the tide of prejudice and false opinions flowing down upon us from the past, and the foundation for a truer and wider knowledge of India in time to come. Its aim has been, not literary graces, nor scientific discovery, nor antiquarian research; but an earnest endeavour to render India better governed, because better understood. ${ }^{131}$

With an army of co-workers he compiled information on each of the 240 districts, publishing the findings in over a hundred volumes. These were later condensed into the nine volumes of The Imperial Gazetteer. ${ }^{132}$ Other series followed; together they were a unique achievement.

In both projects caste was used as a fundamental category of classification. From the outset the Census had a strong interest in ethnology as a means of organizing a massive amount of seemingly disparate data. Thus in addition to age, marital status and sex, the 1871 Census included details of caste and religion in spite of the very real uncertainties that existed. W.R. Cornish, who supervised the Census for Madras, suggested that caste was a 'subject upon which no two divisions or sub-divisions of the people themselves are agreed and upon which European authorities who have paid any attention to it differ hopelessly'. ${ }^{133}$ Later, the supervisor of the 1901 Bombay Census, R.E. Enthoven, argued that the concept of caste used in the Census is 'so hopelessly vague that our figures are useless', and urged it be abandoned. In the event, the recording of caste took on a life of its own. Early in the twentieth century separate 'Castes and Tribes' volumes appeared; Indians consulted them to assess the condition and progress of castes with which they increasingly identified. 


\section{Race and progress}

Hunter organized the Gazetteer as a narrative of progress, but faced the same problems in organizing data as did superintendents of the Census. Like them he had recourse to caste since, as he stated, 'The Census proves that this classification remains the fundamental one to the present day'. ${ }^{134}$ He traced the 'ethnical basis of caste' to the fourfold division of the Vedas. The practical application of this conception of caste, however, proved impossible, for Hunter was astute enough to recognize that this classification had only limited value in understanding the complexities of social and religious divisions in Indian society. In a way redolent of Mill, and even Marx, he attempted to overcome this problem by proposing that the division into varnas is modified by other factors:

But while caste has thus its foundations deep in the distinctions of race, its superstructure is regulated by another system of division, based on the occupations of the people. The early classification of the people may be expressed either ethnically as 'twice-born' Aryans, and 'once-born' non-Aryans; or socially, as priests, warriors, husbandmen, and serfs. On these two principles of classification, according to race and to employment, still further modified by geographical position, has been built up the ethnical and social organization of Indian caste. From the resulting cross-division arises an excessive complexity which renders any brief exposition of caste superficial. ${ }^{135}$

This elaboration also proved unworkable. Not only did it render any uniform plan impossible, but the sheer diversity of India's regions and peoples resisted statistical appropriation. Overall the project produced 'unhappy results' for the investigators; the 'distinctive features of caste, creed, language and the different levels of existence obtaining, tended to undermine the energy and interest of the work' ${ }^{136}$

Hunter's thinking on caste was influenced by the Rev. Sherring, who simultaneously was working on his major study Hindu Tribes and Castes. ${ }^{137}$ 'It appears strange', Sherring declared at the outset, 'that hitherto no one has attempted to give in English a consecutive and detailed account of the castes of India', and he proceeds to make the observation to his 'numerous native friends' that his study has not been undertaken out of 'admiration or respect for ... the peculiar institution of caste'. To the contrary, caste is a 'monstrous engine of pride, dissension, and shame, which could only have been invented by an utterly diseased condition of human society'. ${ }^{138}$ Sherring confronts some of the terminological confusion surrounding caste evident in previous writing:

It is common to speak of the castes of India in their relation to the Hindu religion; and in that light they may be very properly regarded. Yet they sustain another highly important relation. Ethnologically they are so many tribes 
and clans, with separate histories and customs. The members of a caste are, doubtless, united together by peculiar sacred and social ties. In addition, they bear a tribal relation to one another of great significance. Each caste ... is in fact a tribe governed by laws of the most impervious character. ${ }^{139}$

There is a certain logic to these arguments, but it is a flimsy one. The distinction between religiously based and sanctioned castes and ethnologically based tribes lacked rigour, and therefore could not be applied with any degree of consistency. Sherring confusingly organized the first volume around studies of 'Brahmanical tribes' such as the 'Kshatriya or Rajputs', the 'mixed castes and tribes' of the 'Vaisyas and Sudras', and 'aboriginal tribes and lower castes'. This conspicuous lack of success in elaborating the complexities of the caste system did not compromise in any way Sherring's narrative of racial progress. European education, he claimed, was undermining the divine authority of the Brahman, and forcing him to give way to the Kayasth (writer caste) and Vaisya (trading caste) who are 'seizing the golden opportunities that education, civilization, and a thousand favourable circumstances' offer. ${ }^{140}$ Caste relationships have been transformed. Middle and lower castes, which because of their 'presumed impurity of blood, and inherent inferiority, owing ... to the operation of divine laws' had been prevented from escaping from 'prejudice and tyranny', now enjoyed under the influence of British rule the fundamental rights to social and political equality. Even the 'most untamed and vagabond' tribes have been reformed by the 'steady and onward progress of civilization' in India. ${ }^{141}$

This picture of social mobility, however, stands in sharp contrast to the racial hierarchy outlined in Sherring's account of the 'natural history' of Hindu caste. There is in India, he stated, 'an infinite variety of physiognomy, colour, and physique', and he proceeded to provide a taxonomy:

The fair-faced, keen-eyed, aquiline-nosed, and intellectual Brahmin, the stalwart and commanding Rajpoot, the supple Banniah, the conceited yet able Kayasth, or writer, the clever barhai, or carpenter, the heavy-browed lohar, or blacksmith, the wiry and laborious Kumbhi, or agriculturalist, the short and handsome chamar, the dark Pasi, the darker Dom, the wild and semi-barbarous aborigines, and hundreds of other tribes and castes, are in reality so many distinct types of the human family. ${ }^{142}$

Sherring acknowledged the necessary albeit limited nature of such a roughly drawn hierarchy. In reality, he argued, 'the boundary lines dividing the vast Hindu race into multitudinous clans' are 'beyond computation'. ${ }^{143}$ Nowhere, however, does he inquire into how this racial hierarchy is affected by the social transformations brought about by British rule. In important respects Sherring was emblematic of changes that were taking place in the production of knowledge. First, there is in his work a move - 


\section{THE OTHER EMPIRE}

faltering and inconsistent though it might have been - from textual-based theories of caste to ones incorporating observable socio-cultural factors. Secondly, we can also detect a shift that in the long term eclipsed evangelical perspectives. It was significant that Sherring was an Anglican who clearly subscribed to older concerns about Brahmanical tyranny. But his condemnations of the caste system were based less on biblical exegesis than on secular, empirical arguments. Thirdly, he consolidated and systematized racial theories of the caste system. In all these, foundations were being laid for the massive intervention of colonial anthropology made by the Census and imperial gazetteers. ${ }^{144}$

Race and progress provided the articulating principles. Neither was required, ${ }^{145}$ but they had by this time proved their value and versatility in helping to make sense of the complexities of Indian history and society. The idea of progress had since the eighteenth century framed British perspectives on the backwardness of Indian society, and been used to justify colonial expansion. Race, in part the progeny of progress, developed later, and had in embryonic form informed discussions on those features of Indian society that were seen as barriers to the march of civilization. Used in combination toward the end of the nineteenth century, they were to act as a powerful motif. Consider, for example, Hunter's account of the origins of Indian society:

Our earliest glimpses of India disclose two races struggling for the soil. The one was a fair-skinned people, which had lately entered by the north-western passes; a people of ARYAN, literally 'noble' lineage, speaking a stately language, worshipping friendly and powerful gods. The other was a race of a lower type, who had long dwelt in the land, and whom the lordly new-comers drove back before them into the mountains, or reduced to servitude on the plains. The comparatively pure descendants of these two races were in 1872 nearly equal in numbers ... the intermediate castes, sprung chiefly from the ruder stock, make up the mass of the Indian population. ${ }^{146}$

This Aryan theory of race in its most modern manifestation went to the heart of the matter. The history of India was the history of a grim struggle between noble Aryans of Indo-European origin and debased aboriginal races. In this war against savagery the 'conquering stock' of Aryans had triumphed. Where racial mixing occurred, however, degeneration had followed since the purity of Aryan sentiment had become contaminated with base superstition. Founded on readings of Vedic scriptures, endowed with status by Jones's discovery of the commonality of Indo-Aryan languages, this theory was now embraced by ethnologists. In doing so, writers such as Hunter temporalized notions of the caste system, for whereas orientalists had thought of it primarily in terms of cultural difference, ethnologists increasingly located it hierarchically within evolutionary schema. This is 
nicely illustrated by Hunter. In attempting to demonstrate the lineages of cultural prejudice in early racial struggles he looked to the ancient texts, and found there 'scornful epithets for the primitive tribes'. The Aryan, with 'his finely-formed features, loathed the squat Mongolian faces of the Aborigines'. Vedic songs abound with references to tribal people as 'noseless', 'disturbers of sacrifices', 'gross feeders on flesh', 'lawless', 'without gods' and 'without rites'. These peoples were from the plains, where

they have lain hidden away in the recesses of the mountains, like the remains of extinct animals which palaeontologists find in hill caves. India thus forms a great museum of races, in which we can study man from his lowest to his highest stages of culture. The specimens are not fossils or dry bones, but living communities, to whose widely-diverse conditions we have to adapt our administration and our laws. ${ }^{147}$

Hunter proceeds to catalogue and classify the specimens on display using the full repertoire - and terminological confusion - of nineteenth-century racial imagery. The Brahmans, for example, are

the result of nearly 3000 years of hereditary education and self-restraint; and they have evolved a type of mankind quite distinct from the surrounding population. Even the passing traveller in India marks them out, alike from the bronze-cheeked, large-limbed, leisure-loving Rajput or warrior caste of Aryan descent; and from the dark-skinned, flat-nosed, thick-lipped low-castes of non-Aryan origin, with their short bodies and bullet heads. The Brahman stands apart from both; tall and slim, with finely modelled lips and nose, fair complexion, high forehead, and somewhat cocoa-nut shaped skull... He is an example of a class becoming the ruling power in a country, not by force of arms, but by the vigour of hereditary culture and temperance. ${ }^{148}$

Caste thus conceived was not merely an invention of European writers, nor a direct appropriation of ancient Indian thought and practice, but rather the outcome of an ongoing dialogue between the two. This may help to explain the continued imprecision; it certainly accounts for the contrasts in the approaches of Hunter and other prominent ethnologists such as William Crooke, Herbert Risley and Denzil Ibbetson. ${ }^{149}$

From these debates emerged a renewed concern with the degeneration of Indian society. Articulated to notions of caste and race, effeminacy came to be singled out as a crucial symptom of inevitable decline. ${ }^{150}$ As we have seen, many of the early travel accounts commented on the passive and effeminate nature of Bengalis, and the trope continued to feature in contemporary comment, most notably in the writings of Macaulay. After the troubles of 1857 - from which Bengal had remained remote - ethnology provided the means of putting the whole matter on a scientific basis. Hunter and his contemporaries displayed a clear sense of racial vigour, but 
it was with the extensive studies of Risley that effeminacy became a key signifier of degeneration. He concluded that the people of Bengal were of the Mongolo-Dravidian racial stock. They were slightly built and of low stature, an effeminacy he attributed to an enervating climate and diet, and the early maternity of Bengali women. ${ }^{151}$ These ideas were used to great effect to deal with the challenge posed by the Indian middle class to rights and privileges seen to be the preserve of the British. Faced with mounting pressure for reform, British commentators directed attention to the effeminacy of this Western-educated elite. So what had previously been a category applied fairly loosely to the population of Bengal as a whole, was now directed specifically to its bhadralok elite, and the 'Bengali babu' emerged as a figure of ridicule quite unfit for the manly demands of imperial administration.

With the publication of the 1891 Census for Bengal, revised and expanded into the 1908 Tribes and Castes of Bengal, Risley established himself as the leading figure in colonial ethnology. Using the full range of techniques, including anthropometry, and abandoning occupational categories of classification in favour of Brahmanic sociology, Risley sought to prove the primordial role of caste in Indian society. The key to understanding its historic role was race:

race sentiment, ... far from being a figment of the intolerant pride of the Brahman, rests upon a foundation of fact which scientific methods confirm, that it has shaped the intricate groupings of the caste system, and has preserved the Aryan type in comparative purity throughout Northern India. ${ }^{152}$

Risley considered India an ideal laboratory of racial science. Ultimately, his experimental work expressed, and to an extent ameliorated, the ritual anxieties of the Brahman elite, and the racial anxieties of the empire at a time of rapid change. ${ }^{153}$ His findings provided succour to higher castes fearing loss of authority, simultaneously laying the foundation for the rise of communalism. And in pointing to caste as both the bastion against anarchy and the single greatest obstacle to change, he warned Indian and European modernizers of the potentially catastrophic nature of change promoted by idealism. The racial inferiority of Indians justified, even demanded, their continued dominance by Britain. It was, concludes Dirks, a 'bloody legacy that continues to exact a mounting toll'. ${ }^{154}$ With perhaps less momentous consequences, ethnology impacted also on the information order. The long shadow cast by the Census and Imperial Gazetteer eclipsed all other forms of knowledge production. In the last thirty years of the nineteenth century few evangelical or travel accounts of note appeared; those that did tended to reproduce familiar imagery which contributed little to the state of knowledge on Indian society. 


\section{THE GREAT MUSEUM OF RACES}

\section{Notes}

1 Joseph Peggs, Ghaut Murders in India. An Appeal to British Humanity and Justice Respecting the Practice of Exposing the Sick on the Banks of the Ganges, London, Seeley, 1830.

2 Howard Malcolm, Travels in South East Asia, embracing Hindustan, Malaya, Siam and China; with Notices of Numerous Missionary Stations, London, Charles Tilt, 1839 , p. 8.

3 William Campbell, British India in its Relation to the Decline of Hindooism, and the Progress of Christianity ..., London, Snow, 1839, p. iii.

4 Ibid., pp. 9-10.

5 For details of Jervis's manoeuvres see Matthew Edney, Mapping and Empire. The Geographical Construction of British India, 1765-1843, Chicago, University of Chicago Press, 1997.

6 Major Thomas Jervis, Address ... Descriptive of the State, Progress, and Prospects of the Various Surveys, and other Scientific Enquiries, instituted by the Hon. East India Company throughout Asia, Torquay, Private Circulation, 1838, p. 44. As part of his campaign to have his provisional appointment as Surveyor-General confirmed, Jervis arranged to have the address printed privately. It was then distributed with covering hand-written notes to influential contacts, all to no avail.

7 Ibid., p. 10.

8 Major H. Bevan, Thirty Years in India: or, A Soldier's Reminiscences of Nature and European Life in the Presidencies, from 1808 to 1838, London, Pelham Richardson, 1839, p. vi.

9 Ibid., p. 321.

10 Ibid., p. 146.

11 James Massie, Continental India, London, Ward, 1840, pp. xiii-xiv.

12 Ibid., p. 82.

13 Ibid., p. 254.

14 Anon., 'A young civilian in Bengal in 1805', Bengal Past and Present, 29, 1805, p. 125.

15 Walter Hamilton, A Geographical, Statistical and Historical Description of Hindostan, and the Adjacent Countries, London, Murray, 1820, pp. 51-2.

16 Mrs B.H. Holland, The Young Cadet; or Henry Delamere's Voyage to India, London, John Harris, 1827, p. 81.

17 Josiah Conder, The Modern Traveller. A Description, Geographical, Historical and Topographical of the Various Countries of the Globe, 30 vols, London, Duncan, 1830, Vol. III, pp. 49-50.

18 Emma Roberts, Scenes and Characteristics of Hindostan with Sketches of Anglo-Indian Society, London, Allen, 1835, pp. 13-14.

19 Campbell, British India in its Relation to the Decline of Hindooism, p. 5.

20 Massie, Continental India, pp. 99-100.

21 C.J.C. Davidson, Diary of Travels and Adventures in Upper India, London, Henry Colburn, 1843, p. 338.

22 Ibid., p. 6.

23 George Johnson, The Stranger in India; or, Three Years in Calcutta, London, Colburn, 1843, p. 188.

24 William Sleeman, Rambles and Recollections of an Indian Official, London, Hatchard, 1844, p. 76.

25 Ibid., p. 4.

26 Rev. W. Buyers, Recollections of Northern India; with Observations on the Origin, Customs, and Moral Sentiments of the Hindoos, and Remarks on the Country, and Principal Places on the Ganges, ↔c., London, Snow, 1848, p. 23.

27 Ibid., p. 25.

28 Ibid., p. 184.

29 Ibid., p. 209.

30 Ibid., p. 408.

31 Ibid., p. 198. 


\section{THE OTHER EMPIRE}

32 Henry Elliot, Memoirs of the History, of Folk-lore, and Distribution of Races of the North Western Provinces of India, edited, revised and rearranged by John Beames, London, Trubner, 1869, pp. xv-xvi.

33 A. Hervey, Ten Years in India; or, The Life of a Young Officer, London, Schoberl, 1850, pp. iv-v.

34 Ibid., p. 88. A note of caution is struck, however, on the treatment meted out by young officers. They talk of 'those horrible black nigger sepoys [and] look down on them as brute beasts' (p. 88), and as long as this continues, Hervey concludes, 'the poor soldier will be maltreated until his meek and humble spirit becomes roused, his pride hurt, and the consequences are attended with fearful results' (p. 90).

35 J. Gray, Life in Bombay, and the Neighbouring Out-Stations, London, Bentley, 1852, p. viii.

36 M. Wylie, Bengal as a Field of Missions, London, Dalton, 1854, p. 209.

37 Ibid., pp. 35-6.

38 Joseph Mullens, Revised Statistics of Missions in India and Ceylon, compiled at the Request of the Calcutta Missionary Conference, by Rev. Joseph Mullens, Calcutta, Baptist Mission Press, 1852.

39 [Anon.], A Voice from Bombay in Western India - in Behalf of the Spiritual Wants of a Population of 550,000 Souls in Heathen Darkness, London, Seeleys, 1852, p. 11.

40 [M. Wylie], The Bible in India, London, Dalton, 1853, p. 14.

41 Joseph Mullens, Missions in South India, London, Dalton, 1854, p. 3.

42 John Kaye, The Administration of the East India Company; a History of Indian Progress, London, Bentley, 1853.

43 Ibid., p. 3.

44 Ibid., p. 9.

45 Ibid., pp. 13-14.

46 Ibid., pp. 14-16.

47 Ibid., pp. 356-7.

48 Ibid., p. 376.

49 Ibid., p. 407.

50 Ibid., p. 471.

51 Ibid., p. 488.

52 Edward Thornton, A Gazetteer of the Territories under the Government of the East India Company, and of the Native States on the Continent of India, London, Allen, 1857.

53 Petition of the Calcutta Missionaries, for a Royal Commission to Enquire into the Condition of the People of Bengal, London, Sanders, Cones and Co., 1856, p. 16.

54 For an extensive and useful annotated bibliography, see P.J.O. Taylor (ed.), A Companion to the 'Indian Mutiny' of 1857, Delhi, Oxford University Press, 1996.

55 I have relied here on the scholarly syntheses provided in C.A. Bayly, Indian Society and the Making of the British Empire. The New Cambridge History of India Vol. II.1, Cambridge, Cambridge University Press, 1988, and Sugata Bose and Ayesha Jalal, Modern South Asia. History, Culture, Political Economy, Delhi, Oxford University Press, 1999.

56 For a more general survey of the role of the press in reporting India, see David Finkelstein and Douglas Peers (eds), Negotiating India in the Nineteenth-Century Media, Basingstoke, Macmillan, 2000.

57 Eugenie Palmegiano, The British Empire in the Victorian Press, 1832-1867. A Bibliography, New York, Garland, 1987.

58 Rev. John Stevenson, A Sermon, for the Benefit of the Sufferers in India, on the Goodness and Severity of God. Preached at Tinwell, Rutland, 20 September 1857, Stamford, Langley, 1857, p. 6.

59 Ibid., p. 11.

60 Francis Close, An Indian Retrospect, or, What has Christian England done for Heathen India?, London, Hatchard, 1858, p. 3.

61 James McKee, Obstacles to the Progress of Christianity in India, Belfast, Belfast NewsLetter, 1858, pp. 4-5. 


\section{THE GREAT MUSEUM OF RACES}

62 Rev. J. Murray Mitchell, Indian Missions; Viewed in Connexion with the Mutiny and other Recent Events, London, Nisbet, 1859, p. 6.

63 Ibid., p. 16.

64 Ibid., p. 24.

65 Madeline and Rosalind Wallace-Dunlop, A Timely Retreat; or, A Year in Bengal before the Mutinies. By Two Sisters, 2 vols, London, Bentley, 1858.

66 Kataki Kushari Dyson, A Various Universe. A Study of the Journals of British Men and Women in the Indian Subcontinent, 1765-1856, Delhi, Oxford University Press, 1978 , p. 320.

67 Wallace-Dunlop, A Timely Retreat, Vol. I, p. 98.

68 Ibid., p. 112.

69 Ibid., Vol. II, pp. 8-9.

70 Ibid., pp. 89-90.

71 Ibid., p. 90.

72 William H. Russell, My Diary in India in the Year 1858-59, London, 1860, pp. 125-6.

73 Cadwalladar Cummerbund, From Southampton to Calcutta, London, Saunders, Otley and Co., 1860, p. 228.

74 Ibid., pp. 171-2.

75 John Kaye, Kaye's and Malleson's History of the Indian Mutiny of 1857-8, 4 vols, London, 1897-98. The first three volumes were written by Kaye; a fourth was intended but Kaye died before it could be completed. It was finished by G.B. Malleson. Based on extensive research of contemporary evidence, it remains the most authoritative account of the nineteenth century.

76 For the best analyses of Kaye's chapatis and the role of rumour see Ranajit Guha, Elementary Aspects of Peasant Insurgency in Colonial India, Delhi, Oxford University Press, 1983, and Homi Bhabha, 'By bread alone: signs of violence in the mid-nineteenth century', in The Location of Culture, London, Routledge, 1994.

77 R. Montgomery Martin, The Progress and Present State of British India, London, Sampson Low, 1862, pp. vi-vii.

78 Ibid., p. $\mathrm{x}$.

79 Ibid., p. 293.

80 Ibid., pp. 294-5.

81 Rev. John Barton, The Educated Classes of Calcutta, viewed in regard to their Accessibility to Missionary Effort, London, Church Missionary House, 1864, p. 5.

82 For the background to the increased involvement of women like Mary Carpenter in missionary work after 1857 see Steven Maugham, 'Civic culture, women's foreign missions, and the British imperial imagination, 1860-1914', in Frank Trentmann (ed.), Paradoxes of Civil Society. New Perspectives on Modern German and British History, New York, Berghahn, 2000.

83 Mary Carpenter, Six Months in India, 2 vols, London, Longmans, Green and Co., 1868, Vol. II, pp. 80-1.

84 Mary Carpenter, Addresses to the Hindoos, delivered in India, London, Longmans, Green and Co., 1867, p. 5.

85 Ibid., p. 6.

86 Carpenter, Six Months in India, Vol. II, p. 108.

87 Ibid., p. 55. See also Antoinette Burton's study of this text, 'Fearful bodies into disciplined subjects: pleasure, romance and the family drama of colonial reform in Mary Carpenter's Six Months in India', Signs, 20:3, Spring 1995, pp. 545-74.

88 Carpenter, Addresses to the Hindoos, p. 8.

89 Memoir of George E.L. Cotton, Bishop of Calcutta, and Metropolitan. With Selections from his Journals and Correspondence. Edited by Mrs. Cotton, London, Longmans, Green and Co., 1871, pp. 80-1.

90 Ibid., p. 331.

91 William Butler, The Land of the Veda, being Personal Reminiscences of India; its People, Castes, Thugs, and Fakirs ..., New York, Phillips and Hunt, 1871, p. 11.

92 Ibid., p. 40.

93 Ibid., p. 402. 


\section{THE OTHER EMPIRE}

94 See the tables reproduced on pp. 529-31.

95 Maughan, 'Civic culture, women's foreign missions, and the British imperial imagination'.

96 Herbert Blackett, Two Years in an Indian Mission, London, SPCK, 1884, pp. 9-10, 12, 15.

97 James Bradbury, India, its Condition, Religion and Missions, London, Snow, 1884, p. 8 .

98 Ibid., p. 24.

99 E.C.P. Hull, The European in India; or, Anglo-Indian's Vade Mecum, London, King, 1871 , p. viii.

100 Ibid., p. 39.

101 Ibid., pp. 43, 45.

102 [Edward Eastwick], Handbook of the Madras Presidency, London, Murray, 1879; Handbook of the Bombay Presidency, London, Murray, 1881; Handbook of the Bengal Presidency, London, Murray, 1882; Handbook of the Panjab, Rajputana, Kashmir and Upper Sindh, London, Murray, 1883. These were condensed into a single volume in 1892, which was revised seven times in the ensuing decade.

103 Cited in Handbook of the Madras Presidency, pp. xi-xii.

104 Handbook of the Bengal Presidency, pp. 34-5.

105 C.A. Bayly, Empire and Information. Intelligence Gathering and Social Communication in India, 1780-1870, Cambridge, Cambridge University Press, 1996, p. 338.

106 Cited in Susan Bayly, Caste, Society and Politics in India from the Eighteenth Century to the Modern Age. The New Cambridge History of Modern India Vol. IV.3, Cambridge, Cambridge University Press, 1999, p. 106.

107 William Robertson, An Historical Disquisition concerning the Knowledge which the Ancients had of India, London, Cadell and Davies, 1817 [1791], p. 200.

108 Ibid., p. 201.

109 Abbe J.A. Dubois, Description of the Character, Manners, and Customs of the People of India, and of Their Institutions, Religious and Civil, translated and edited by Henry Beauchamp as Hindu Manners, Customs and Ceremonies, Oxford, Clarendon Press, 1906. The origins and publication of the manuscript are well described by Nicholas Dirks, Castes of Mind. Colonialism and the Making of Modern India, Princeton, Princeton University Press, 2001.

110 Cited in Dirks, Castes of Mind, p. 24.

111 Duncan Forester, Caste and Christianity. Attitudes and Policies on Caste of AngloSaxon Protestant Missions in India, London, Curzon Press, 1980, p. 35.

112 G.A. Oddie, Social Protest in India. British Protestant Missionaries and Social Reforms, 1850-1900, Delhi, Manoher, 1979, p. 56.

113 Charles Grant, Observations on the State of Society among the Asiatic Subjects of Great Britain, particularly with reference to Morals; and on the Means of Improving it. - Written chiefly in the Year 1792, Parliamentary Papers, 1813, p. 28.

114 James Forbes, Oriental Memoirs, 4 vols, London, White, Cochrane and Co., 1813, Vol. I, p. 73.

115 Cited in Ronald Inden, Imagining India, Bloomington, Indiana University Press, 2000 [1990], p. 57.

116 Dirks, Castes of Mind, p. 34.

117 In fairness, Mill was later to develop his ideas in the 1824 supplement of the Encyclopaedia Britannica. He located caste within the broad history of the division of labour, and the transition from a pastoral to an agricultural mode of production. Contradictions between the economic and religious exigencies, however, remained unresolved. See Louis Dumont, Homo Hierachicus. The Caste System and its Implications, Chicago, University of Chicago Press, 1980 [1966], p. 24.

118 William Ward, A View of the History, Literature, and Religion of the Hindoos, 4 vols, London, British Missionary Society, 1817-20, Vol. III, p. xxviii.

119 Ibid., p. 69.

120 Bayly, Caste, Society and Politics in India, p. 110.

121 Walter Hamilton, A Geographical, Statistical and Historical Description of Hindostan, 


\section{THE GREAT MUSEUM OF RACES}

and the Adjacent Countries, London, Murray, 1820, p. 102.

122 Lt. Col. Fitzclarence, Journal of a Route across India, through Egypt to England in the latter end of the Year 1817, and the beginning of 1818, London, Murray, 1819, p. 105.

123 R. Montgomery Martin, The History, Antiquities, Topography, and Statistics of Eastern India, 3 vols, London, Allen, 1838, Vol. I, p. 126.

124 This tends to be suggested not only by the lack of reference in travel and evangelical accounts, but also by silences on this period in all of the recent studies. Dumont, Dirks, Inden and Bayly have little to say, choosing instead to jump from Mill to 1857, even to Risley at the end of the century. The intellectual history of Western conceptions of caste awaits its scholar.

125 Cited in Forrester, Caste and Christianity, p. 38.

126 Bayly, Caste, Society and Politics in India, p. 122.

127 Christopher Pinney, 'Colonial anthropology in the "laboratory of mankind"', in C.A. Bayly (ed.), The Raj. India and the British 1600-1946, London, National Portrait Gallery Publications, 1990, pp. 252-63.

128 For an early but worthy foray into it, see S.B. Chaudhuri, History of the Gazetteers of India, Delhi, Ministry of Education, 1964.

129 Kenneth Jones, 'Religious identity and the Indian Census', in N. Gerald Barrier (ed.), The Census in British India. New Perspectives, Delhi, Manohar, 1981. For a useful bibliography on the Census, see Richard Martin, 'Bibliographic notes on the Indian Census', in the same collection.

130 William Hunter, The Imperial Gazetteer of India, London, Trubner, 1881, p. ix.

131 Ibid., p. xxx.

132 By far the most accessible and popular form of the Gazetteer, however, was the updated single-volume digest Hunter compiled in 1886 (William Hunter, The Indian Empire. Its People, History and Products, London, Trubner, 1886).

133 Cited in Frank Conlon. 'The Census of India as a source for the historical study of religion and caste', in Barrier (ed.), The Census in British India, p. 108.

134 Hunter, The Indian Empire, p. 192.

135 Ibid., p. 192.

136 Chaudhuri, History of the Gazetteers of India, p. 16.

137 Rev. M.A. Sherring, Hindu Tribes and Castes, 3 vols, London, Trubner, 1872-81. Vol. I dealing with Brahmanical, Kshatriya or Rajpoot tribes, mixed castes and tribes of Vaisyas and Sudras, and Aboriginal tribes and inferior castes around Benares appeared in 1872 , Vol. II covering the north-west frontier and central provinces appeared in 1879, and Vol. III covering Rajputna and Madras appeared in 1881, after Sherring's death. Also important at the time were the writings of George Campbell: for example, 'On the races of India as traced in existing tribes and castes', Quarterly Ethnological Journal, 1:2, 1876.

138 Sherring, Hindu Tribes and Castes, Vol. I, p. iv.

139 Ibid., p. xxiii.

140 Ibid., pp. 4-5.

141 Ibid., p. 387.

142 Ibid., Vol. III, p. 218.

143 Ibid., p. 219.

144 The broad contours of this intervention have recently been traced by Bayly, Caste, Society and Politics in India, and Dirks, Castes of Mind.

145 In what remains one of the most perceptive discussions of how racial categories were applied in India, Peter Robb has argued that late nineteenth-century perceptions of Indian society 'did not require the term "race", but that was the word around which they were to gather' (Peter Robb, 'South Asia and the concept of race', in Robb (ed.), The Concept of Race in South Asia, Delhi, Oxford University Press, 1997). The same obtains for 'progress'.

146 Hunter, The Indian Empire, p. 52.

147 Ibid., p. 54.

148 Ibid., p. 96.

149 William Crooke, The Native Races of the British Empire: Natives of Northern India, 
THE OTHER EMPIRE

London, 1907; Herbert Risley, The People of India, London, 1908; Denzil Ibbetson, Panjab Castes, Delhi, Low Price Publications, 1993, first published as part of the 1881 Census of the Panjab. Crooke and Ibbetson, while sharing with Hunter founding concepts on civilization and Aryan stock, dismissed the excesses of racial theory (Susan Bayly, 'Caste and "race" in colonial ethnography', in Robb (ed.), The Concept of Race in South Asia, p. 205). Both emphasized the role of occupation. 'The whole basis of diversity of caste', wrote Ibbetson, 'is diversity of occupation' (Ibbetson, Panjab Castes, p. 3).

150 Mrinalini Sinha, Colonial Masculinity. The 'Manly Englishman' and the 'Effeminate Bengali' in the Late Nineteenth Century, Manchester, Manchester University Press, 1995.

151 Ibid., p. 20.

152 Cited in Dirks, Castes of Mind, p. 213.

153 Ibid., p. 225.

154 Ibid., p. 227. 